\title{
Gout in the elderly, a separate entity?
}

\author{
EVERT JAN TER BORG* AND JOHANNES J RASKER
}

From the Rheumatology Department of Ziekenhuis Ziekenzorg and De Stadsmaten, Enschede, The Netherlands

SUMmARY To evaluate whether the clinical pattern of gout differed between elderly women and岕 men a retrospective study was performed in all women (22) and men (18) in our rheumatological clinics who developed gout after the age of 60 . The diagnosis was made after a mean of $2 \cdot 6$ years $s^{\circ}$ of joint complaints in women and after 1.2 years in men. In about half the patients complaints. started in more than one joint, often including the big toe. In five women, but none of the men, complaints started in the fingers. No correlation was found between gout and the presence of ${ }_{\circ}^{N}$ tophi or Heberden's nodes in the finger joints. The mean uric acid level was higher in women? $(0.61 \mathrm{mmol} / \mathrm{l})$ than in men $(0.53 \mathrm{mmol} / \mathrm{l})$, and almost all the women $(95 \%)$ used diuretics and only $\mathrm{y}_{\mathrm{c}}$ $56 \%$ of the men did so.

During recent years we have had the impression that we were seeing more older women in our clinics with atypical gout. They were seldom extremely overweight and the complaints did not start acutely in one joint, but gradually in several and often in the finger joints. To evaluate whether the disease pattern of gout in older women differed from that of older men we carried out a retrospective study in all men and women in our clinics who developed gout after the age of 60 .

\section{Patients and methods}

PATIENTS

All men and women were included who developed gout after the age of 60 and who were seen between 1978 and 1982. The diagnosis was made on the following criteria: (poly)arthritis with urate crystals found in a joint or in a tophus, or classical podagra with increased serum urate and good clinical response to colchicine.

\section{METHODS}

Several items were checked using the clinical notes. To obtain supplemental data patients were recalled to the clinics and questioned. These items were: the referral diagnosis, history of pre-existing diseases, the history of their gouty arthritis, the time between

Accepted for publication 25 Junc 1986.

Correspondence to Dr Johannes J Rasker, Zickenhuis Zickenzorg, Haaksbergerstraat 55, 7513 ER Enschede, The Netherlands.

*Present address: Department of Internal Medicine, University Hospital, Groningen, The Netherlands. first arthritic symptoms and diagnosis, which joint $\overrightarrow{0}$ were affected first, how many joints were affected, when the diagnosis was made, a family history of gout, alcohol consumption, and coincidentak medications.

The findings which were routinely noted at the first examination included the signs of arthritis and the presence of tophi and Heberden's nodes.

As normal weight we took the mean weighs correlated for age and height $\pm 15 \%$. $^{1}$

LA B ORATORY IN VESTIGATIONS

At the first clinical investigation laboratory test included serum urate (kinetic aldehyde dehydo rogenase, UV $340 \mathrm{~nm}$ ), ${ }^{2}$ fasting cholesterol ${ }^{3}$ an ${ }^{\nexists}$. triglycerides ${ }^{4}$ by an enzymatic method, creatinine clearance (and, if not available, serum creatinine) and urinary excretion of uric acid/24 $\mathrm{h}$ during purine restricted diet.

$x$ Rays were scored for the presence of the characteristic bony defects of gout ${ }^{5}$ and osteoarth rosis.

Joint aspiration was performed in most patients a佔 the first visit and examined for crystals with polar ised light microscopy.

\section{Results}

One hundred and sixty four patients with gout were seen between 1978 and 1982 (29 women and 13ز men). Of these, 22 women and 23 men develope gout after the age of 60 years. Two male patient had already started allopurinol therapy, and in three 
cases the notes were not available. Thus 22 women and 18 men were included in this study. They were all Caucasians; mean age at diagnosis in women was 73.1 years (SD 6.6, range 60-86) and in men $70 \cdot 2$ years (SD 6.9, range 61-86). The mean weight of the women was $74.9 \mathrm{~kg}$ (SD 10.7, range 58-102) and of the men $78 \mathrm{~kg}$ (SD 12.2, range 58-102). Two of the women were extremely overweight $(+12$ and $+24 \mathrm{~kg})$, eight were mildly overweight $(+5 \mathrm{~kg})$, none were underweight, and in two the weight was not noted at the first visit. Of the men, two were extremely overweight $(+16$ and $+15 \mathrm{~kg})$, two were mildly overweight $(+2$ and $+5 \cdot 2 \mathrm{~kg})$, none were underweight, and in two the weight was not known. Diagnostic joint aspiration was performed in 17 women and $15 \mathrm{men}$; in 15 of the women and 13 of the men negatively birefringent urate crystals were found.

\section{REFERRAL DIAGNOSIS}

Most patients were referred as having 'joint pains' (12 women and 10 men); fourteen as gout (seven women), and one each as rheumatoid arthritis, deep venous thrombosis, erysipelas, and arterial insufficiency.

\section{DISEASE DURATION}

Before diagnosis was made complaints of arthritis had existed for a mean period of 2.6 years in women and 1.2 years in men. This period was less than one month in six women and eight men, from one to two months in three women and three men, and longer than 12 months in nine women and five men (in four women and two men it was not recorded). In nine men and nine women the complaints started in two or more joints (polyarticular) and in 11 women and seven men in one (incomplete data in other patients). In most cases the arthritic complaints started

Table 1 Localisation of first complaints in the joints

\begin{tabular}{|c|c|c|c|c|}
\hline & \multicolumn{2}{|c|}{ Women $(n=20)$} & \multicolumn{2}{|c|}{ Men $(n=16)$} \\
\hline & $n$ & $(\%)$ & $n$ & $(\%)$ \\
\hline $\begin{array}{l}\text { First metatarsophalangeal } \\
\text { (MTP) joint }\end{array}$ & 8 & (40) & 8 & $(50)$ \\
\hline $\begin{array}{l}\text { Foot (localisations other } \\
\text { than MTP-1) }\end{array}$ & 7 & (35) & 6 & (38) \\
\hline Ankle & - & - & 3 & (19) \\
\hline Knee & 5 & (25) & 2 & (13) \\
\hline Wrist & - & - & 2 & (13) \\
\hline Fingers & 5 & (25) & - & - \\
\hline Elbow & - & - & 1 & (6) \\
\hline Shoulder & - & - & 1 & (6) \\
\hline Two or more joints & 9 & $(45)$ & 9 & $(56)$ \\
\hline Not known & 1 & (5) & - & - \\
\hline
\end{tabular}

Table 2 Diagnosis made before presentation of patients to the rheumatological clinic

\begin{tabular}{lccccc}
\hline & \multicolumn{2}{c}{ Women $(n=22)$} & & \multicolumn{2}{c}{ Men $(n=18)$} \\
\cline { 2 - 3 } & $n$ & $(\%)$ & & $n$ & $(\%)$ \\
\hline Hypertension & 16 & $(73)$ & & 7 & $(39)$ \\
Decreased renal function & 11 & $(50)$ & & 4 & $(22)$ \\
Myocardial infarction & 4 & $(18)$ & & 6 & $(33)$ \\
Cardiac failure & 4 & $(18)$ & & 2 & $(11)$ \\
Coronary insufficiency & 7 & $(32)$ & & 1 & $(6)$ \\
Atrial fibrillation & 5 & $(23)$ & & 1 & $(6)$ \\
Diabetes mellitus & 8 & $(36)$ & & 1 & $(6)$ \\
Cholecystectomy & 4 & $(18)$ & & 1 & $(6)$ \\
Chronic bronchitis & - & - & & 3 & $(17)$ \\
Renal stones & 1 & $(5)$ & & 1 & $(6)$ \\
\hline
\end{tabular}

in the big toe or feet (Table 1). In five women complaints started exclusively in the fingers.

During the first visit only five women complained of one joint, seven of two to four joints, and nine of them had arthritis in five joints or more (incomplete data in one patient). Of the men, seven complained of one joint, seven of two to four joints, and only one of more than four joints (incomplete data in three patients).

A family history of gout existed in three of the women and none of the men.

Alcohol consumption was very moderate: only one woman and two men took more than 20 grams of ethyl alcohol a day.

Diuretics were taken regularly by 21 women (95\%) and 10 men (56\%); these included hydrochlorothiazide, frusemide, or chlorthalidone. It was not possible to find out for how long they had been taken. A great number of further medications were taken as might be expected in this age group (in women a mean of 3.8 and men a mean of 2.4$){ }^{6}$ Women took more medicaments than men, especially digoxin ( 12 women, three men) and $\beta$ blockers (eight women, four men). Other drugs taken equally by men and women included coumarins (11), other antihypertensive drugs (nine), analgesics (six), and oral hypoglycaemics (two). None of the patients took salicylates.

Most patients had an extensive non-rheumatological disease history as summarised in Table 2. Hypertension was found more frequently in women $(73 \% v 39 \%)$, as was coronary insufficiency (32\% v 6\%), impaired renal function $(50 \% v 22 \%)$, and diabetes mellitus $(36 \% v 6 \%)$. None had proteinuria and only two had kidney stones, both a long time before gouty symptoms appeared. None of the patients had secondary gout due to blood dyscrasia, none had Paget's disease or hyperparathyroidism. Only in six men was a provoking event 
Table 3 Localisation of gouty arthritis at first visit

\begin{tabular}{|c|c|c|c|c|}
\hline & \multicolumn{2}{|c|}{ Women $(n=22)$} & \multicolumn{2}{|c|}{ Men $(n=18)$} \\
\hline & $n$ & $(\%)$ & $n$ & $(\%)$ \\
\hline Big toe & 14 & (64) & 8 & (44) \\
\hline Knee & 7 & (32) & 3 & (17) \\
\hline Foot (except big toe) & 5 & (23) & 4 & (22) \\
\hline Ankle & 6 & (27) & 3 & (17) \\
\hline Fingers: dist. interphal. joint & 3 & (14) & 0 & - \\
\hline prox. interphal. joint & 4 & (18) & 1 & (6) \\
\hline metacarpophal. joint & 1 & $(5)$ & 0 & - \\
\hline Wrist & 2 & (9) & 1 & (6) \\
\hline Elbow & 0 & - & 1 & (6) \\
\hline No active arthritis & 0 & - & 1 & (6) \\
\hline
\end{tabular}

recorded at the beginning of the disease: operation (two), infection (one), severe diarrhoea (one), excessive alcohol intake (one), and a fall followed by hospital admission (one).

On physical examination at the first visit arthritis was found in the big toe in 14 women $(64 \%)$ and eight men (44\%) (Table 3). The small finger joints were especially affected in women $(n=7(32 \%))$ (Fig. 1) and only in one man (6\%). Tophi were found in seven women and five men, with two ear tophi only in men, on the elbow in two women, on the distal interphalangeal finger joints in two women only, on the first MTP joints in two women and one man, and in other joints in one woman and two

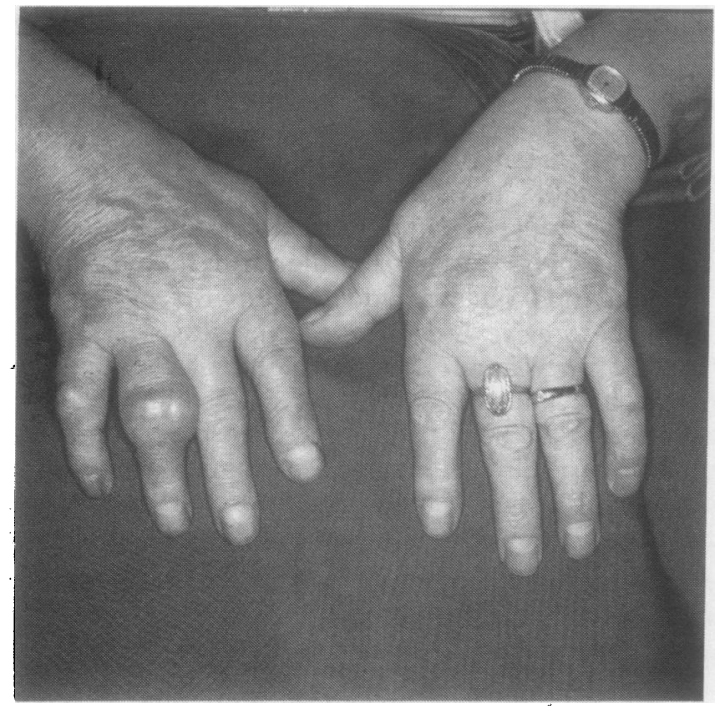

Fig. 1 Hands of a woman with typical tophaceous gout. She was diagnosed elsewhere as osteoarthritic for several years. men. Heberden's nodes were noted in one man $\frac{0}{\omega}$ $(6 \%)$ and nine women $(41 \%)$. In only two of these women was gouty arthritis with urate crystals $\stackrel{\oplus}{+}$ present in or near these Heberden's nodes; one hado a tophus in this situation. In the other patients no흐 signs of gout were seen in or near the Heberden's nodes.

LA B ORATORY RESULTS

Serum urate levels (without urate reducing medi- $\vec{\circ}$ cation) were available in 18 women and all 18 men; normal values $(\mathrm{N})$ were found in four men $(\mathrm{N}<0.42 \mathrm{mmol} / \mathrm{l} ;$ in all the other men and all women $(\mathrm{N}<0.36 \mathrm{mmol} / \mathrm{l})$ they were raised. The mean values? for women were $0.61 \mathrm{mmol} / \mathrm{l}$ (SD 0.12 , range 0.38 -? $0.82 \mathrm{mmol} / \mathrm{l})$ and for the men $0.53 \mathrm{mmol} / \mathrm{l}\left(\mathrm{SD}_{\overrightarrow{\mathrm{v}}}\right.$ $0 \cdot 12$, range $0 \cdot 38-0.79 \mathrm{mmol} / \mathrm{l})$. Creatinine clearance $\mathrm{N}$ $(\mathrm{N}>95 \mathrm{ml} / \mathrm{min}$ ) was reduced in 11 women and 을 eight men with a mean of $56 \mathrm{ml} / \mathrm{min}$ in women (SD 20, range $26-89 \mathrm{ml} / \mathrm{min}$ ) and $62.5 \mathrm{ml} / \mathrm{min} \cong$ (SD $11 \cdot 7$, range $49-83 \mathrm{ml} / \mathrm{min}$ ) in men. In only two women was it less than $40 \mathrm{ml} / \mathrm{min}(38$ and $26 \mathrm{ml} / \mathrm{min} \stackrel{\text { ڤ }}{2}$ respectively).

In the other patients serum creatinine was $\stackrel{\oplus}{\oplus}$ measured (normal in women $<90 \mu \mathrm{mol} / \mathrm{l}$, in men. $<110 \mu \mathrm{mol} / \mathrm{l})$. The mean value in these 11 women was $137.5 \mu \mathrm{mol} / \mathrm{l}$ (SD 61.6, range 77-283 $\mu \mathrm{mol} / \mathrm{l})$ and in these $10 \mathrm{men} 145.6 \mu \mathrm{mol} / \mathrm{l}$ (SD $97 \cdot 8$, range $90-250 \mu \mathrm{mol} / \mathrm{l})$. In only two women and two men were normal values found. In six women values $\stackrel{\mathbb{Q}}{2}$ were found between 90 and $150 \mu \mathrm{mol} / \mathrm{l}$ and twice $\overrightarrow{\vec{\rho}}$ above $150 \mu \mathrm{mol} / \mathrm{l}$ (197 and $283 \mu \mathrm{mol} / \mathrm{l}$ respectively).

URIC ACID EXCRETION IN THE URINE

Apart from two men who had an increased excretion (3.84 and $4.12 \mathrm{mmol} / 24 \mathrm{~h}$ respectively) urinary uric $\overline{\underline{.}}$ acid excretion was normal in the other eight men and 10 women in whom it was measured.

Fasting serum cholesterol was normal in 11 of 16 응 women, in five it was raised (mean $6.8 \mathrm{mmol} / \mathrm{l}$, range $3 \cdot 5-9 \cdot 8$, normal $<7.5 \mathrm{mmol} / \mathrm{l})$. In men it was normal in six out of seven cases (mean $6.0 \mathrm{mmol} / \mathrm{l}, \mathrm{D}$ range $3 \cdot 50-8 \cdot 40)$. Out of nine triglyceride values in women, seven were raised (mean $4.4 \mathrm{mmol} / \mathrm{l}$, range $\mathrm{N}$ $1 \cdot 2-7 \cdot 6$ ), four of these had diabetes mellitus. In men four out of five were raised (mean $2.70 \mathrm{mmol} / \mathrm{l}$, range $1 \cdot 30-4 \cdot 10$, normal $<2 \cdot 00 \mathrm{mmol} / \mathrm{l}$ ).

$x$ RAY STUDIES

In 17 women and 11 men $x$ ray pictures were taken, mainly of feet, hands, and sometimes knees. In nine? women and three men these showed osteoarthrosis; $\frac{T}{3}$ in seven women and six men gouty abnormalities $\frac{\vec{D}}{\mathrm{D}}$ were seen (Fig. 2). No abnormalities compatible with RA were seen. 


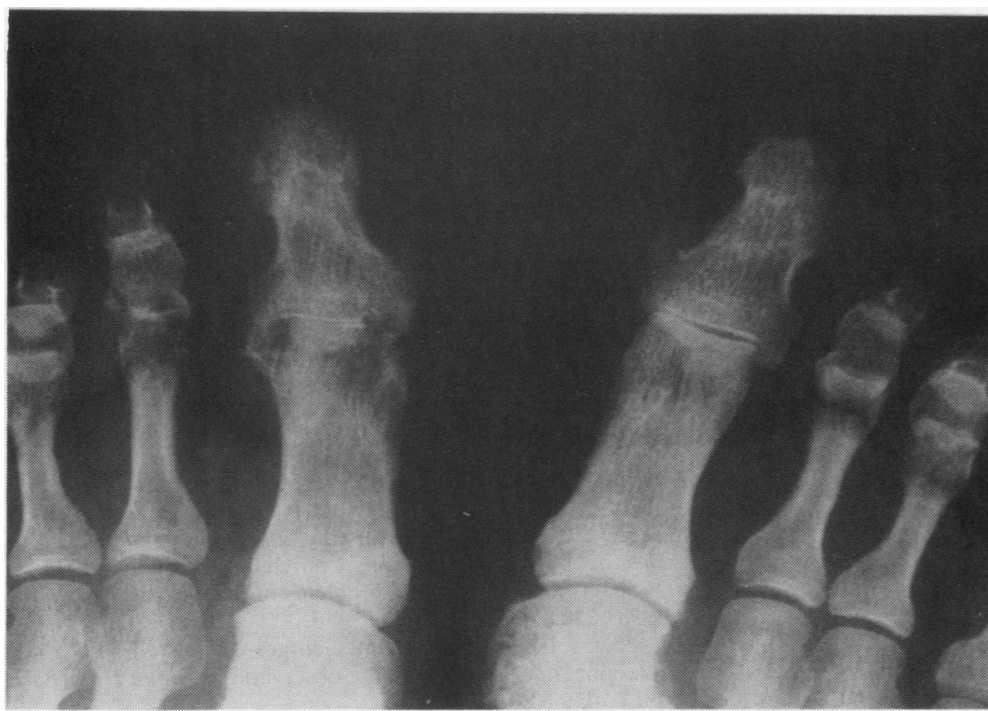

Fig. 2 Circumscribed erosions and cysts in first interphalangeal joint, typical for gout.

\section{Discussion}

Several large series of patients with gout have been recorded, ${ }^{7-9}$ but none of these studies paid special attention to the clinical and laboratory features of gout with onset in old age. All of these studies were retrospective. In this study of 164 patients with gout $17.7 \%$ were women; this figure is higher than that seen in previous studies of $5 \cdot 6 \%{ }^{7}$ and $9 \cdot 7 \% .^{8}$ In our study gouty arthritis started at 60 years or older in $75 \%$ of the women, compared with $22.5 \%{ }^{7}$ and $27.9 \%{ }^{8}$ in previous studies. In men gout started at 60 years or older in $17 \%$ compared with $9.6 \%$ in Grahame and Scott's study. ${ }^{8}$

Many factors may cause or contribute to hyperuricaemia ${ }^{10}{ }^{\text {including age }}{ }^{11}$ and diuretics. ${ }^{12}$ In our series $95 \%$ of the women used diuretics, mainly for hypertension and cardiac failure. Macfarlane and Dieppe recently described a series of 60 gouty patients, in which all nine women were receiving diuretics but only $33 \%$ of the men, ${ }^{13}$ figures comparable with ours. Regular alcohol consumption was an exception in our series in contradiction with for example Raddatz et al, who noted chronic alcoholism in $32 \% .{ }^{14}$ Grahame and Scott found $15 \%$ only in women of all ages but in men $40.2 \% .^{8}$ In the series of Delbarre et al $10 \%$ drank one litre or more of wine daily. ${ }^{7}$

Only two men and two women were extremely fat in our series, but $8 / 18(44 \%)$ of the women and $2 / 22$ $(9.1 \%)$ of the men were mildly overweight. This percentage in men is less than the $45 \%$ of overweight men found by Raddatz et al ${ }^{14}$ and Grahame and Scott. ${ }^{8}$ Our figures suggest that obesity is less frequently seen in patients whose gout starts in old age.

Renal function was mildly decreased in $90 \%$ of the patients, a similar result to the findings of Grahame and $\operatorname{Scott}^{8}$ and of Delbarre et al. ${ }^{7}$ In our series the decreased renal function was mainly compatible with age ${ }^{15}$ and not due to gout as no proteinuria was seen and only in two cases a history of renal stones in the far past.

Uric acid excretion was normal or low in all 10 women and eight out of 10 men who were investigated. Delbarre et al found low urate excretion in $96 \%$ of his female patients versus $38 \%$ of the men. ${ }^{7}$ Urine estimations of uric acid excretion will be inaccurate if the creatinine clearance is less than $40 \mathrm{ml} / \mathrm{min} .{ }^{16}$ This was only the case in two of the women and none of the men. The low urate excretion may be partly explained by the use of diuretics. ${ }^{17} 18$ One may conclude that a decreased excretion was the major cause of hyperuricaemia and gout in our series. The role of age in the relative impairment of urate excretion resulting in increased concentrations of serum urate remains an important topic for further investigation as a compensatory increase of urate clearance per nephron occurs when creatinine clearance declines with age. ${ }^{19}$

In our series the diagnosis of gout was made at variable times after onset of symptoms, and in nine women and five men was delayed for more than a year. Indeed, the referral diagnosis was gout in only seven men and seven women. It is likely that the diagnosis was delayed more frequently in women 
than in men because of an osteoarthritis-like course in women. The same was also found by Delbarre $e t$ $a l,{ }^{7}$ and it is possible that a doctor is more inclined to think of gout as the diagnosis in a man with a painful big toe than in a woman with a polyarthritic pattern of joint involvement. A polyarticular onset was seen in almost half of our patients, and, at referral, more than one inflamed joint was found in 17 women and 11 men on examination. It is suggested that a polyarticular presentation of gout may be seen more frequently nowadays. ${ }^{89142021}$

In our series gouty arthritis and tophi on the hands were found more frequently in women than in men. In Delbarre's series of female patients the first attack was in the fingers in $10 \%$ only, but in $65 \%$ of the cases the fingers were affected in the course of the disease. ${ }^{7}$ They found tophi in $62 \%$ of women and $55 \%$ of men, which may be explained by the fewer methods of treatment that existed in those days. In women the tophi were mostly found in the fingers $(86 \% v 67 \%$ in men) and seldom in the ear ( $16 \%$ in women $v 51 \%$ in men). ${ }^{7}$ A relation between gout and Heberden's nodes is suggested by Simkin $e t$ al, who describe five patients with acute gouty arthritis or tophi in distal interphalangeal joints. ${ }^{22}$ In our series nine women had Heberden's nodes, and in only two of these did gouty arthritis coexist and a tophus in one; these findings do not support the thesis that osteoarthritic changes in the fingers may induce local gouty abnormalities.

In none of our female patients was a provoking incident seen compared with one third by others. ${ }^{7}$ in

A family history was found in only three of our 40 patients $(7 \cdot 5 \%)$. This is a lower figure than that found by Grahame and Scott ${ }^{x}$ and by Delbarre et $a l .^{7}$ In gout of old age hereditary factors may have a minor role. At first visit normal serum uric acid values were found in none of the women and $22 \%$ of the men, making clear again that normal values do not exclude the diagnosis of gout. Wallace et al mentioned normal uric acid values in $7.8 \%$ of the patients during a long follow up period. ${ }^{23}$

There were no cases of Paget's disease in our series, though there is an increased risk for gout in this population. ${ }^{24}$ Other diseases found in our patients were: hypertension, myocardial infarction, and diabetes mellitus. In women mild hypertriglyceridaemia was frequently found in contradiction with Macfarlane who did not find hypertriglyceridaemia in eight women with late onset gout. ${ }^{25}$ This may partly be explained by the fact that their patients were seldom overweight.

The elderly patients we have studied portray only a small part of the clinical spectrum of gout and it is important to recognise gout with an atypical course particularly in lean elderly men and women, thus saving them from long years of unnecessary $\frac{\mathrm{T}}{\mathrm{O}}$ suffering.

We wish to thank Dr J J M Festen and Dr M W M Kruijsen for $\overline{\bar{ज}}$ allowing us to include their paticnts, Professor G S Panayi for his 7 valuable suggestions and Mrs W H Verduin-Keppel for typing the manuscript.

\section{References}

1 Build and blood pressure study. Vol. 1. Chicago: Soc of $\stackrel{\mathbb{D}}{\varrho}$ Actuaries, 1959: 16.

2 Kageyama N. A direct colorimetric determination of uric acid $\tilde{S}$ in serum and urine with uricase-catalase system. Clin Chim Acta $\overrightarrow{0}$ 1971; 31: 421-6.

3 Morin R J. Rapid enzymatic determination of free and $\overrightarrow{\vec{\omega}}$ esterified cholesterol content of serum and tissues. Clin Chim Acta 1976; 71: 75-80.

4 Arntz H R. Diagnostik der Hyperlipoproteinhämien. Lab Med 르 1979; 3: 177 .

5 Scott J T. In: Scott J T. ed. Copeman's textbook of the rheumatic diseases. London: Churchill Livingstone, 1978.

6 Williamson J. Prescribing problems in the elderly. Practitioner $\mathrm{N}$ 1978; 220: 749-55.

7 Delbarre F. Braun S, Saint Georges-Chaumet F. La goutte féminine, analyse de quarante observations. Semin Hôp (Paris) 1967: 43: 623-33.

8 Grahame R. Scott J T. Clinical survey of 354 patients with gout. Ann Rheum Dis 1970); 29: 461-8.

9 Dauthy $\mathbf{M}$. Histoire naturelle de la goutte. University of Paris, 1963 (after Delbarre ${ }^{7}$ ). (Thèse Médicine).

10 Scott J T. Factors inhibiting the excretion of uric acid. Proc $R \stackrel{\infty}{\infty}$ Soc Med 1966; 59: 310-2.

11 Glynn R J, Campion E W. Silbert J E. Trends in serum acid levels. Arthritis Rheum 1983; 26: 87-93.

12 Hall A P. Barry P E. Dawber T R. McNamara P M. Epidemiology of gout and hyperuricaemia. Am J Med 1967; 42: $\overline{\bar{O}}$ 27-37.

13 Macfarlane D G, Dieppe P A. Diuretic gout in elderly women. Br J Rheumatol 1985; 24: 155-7.

14 Raddatz D A. Mahowald M L. Bilka P J. Acute polyarticular $\overline{\bar{O}}$ gout. Ann Rheum Dis 1983; 42: 117-22.

15 Friedman S A. Raizner A E, Rosen H, Solomon N A. Wilfredo $\mathrm{S}$ Y. Functional defects in the aging kidney. Ann Intern Med 1972: 76: 41-5.

16 Dieppe P A, Calvert P. Crystals and joint disease. London. NY: Chapman and Hall. 1983: 249-50.

17 Dorhout Mees E J. Urinezuurstofwisseling in het bijzonder de invloed van diuretica daarop. Ned Tijdschr Geneeskd 1979; 123:ב‥ 1468-75.

18 Kelley W N. Gout and related disorders of purine metabolism. In: Kelley W N, Harris E D, Ruddy S, Sledge C B. eds. Textbook of rheumatology. 1st ed. Philadelphia: Saunders, 윽 1981: 1416.

19 Rieselbach R E. Steele T H. Influence of the kidney upon uratc $\frac{D}{2}$ homeostasis in health and discase. Am J Med 1974; 56: 665-75. 三.

20 Hadler N M, Franck W A, Bress N M, Robinson D R. Acute N polyarticular gout. Am J Med 1974; 56: 715-9.

21 Simkin P A. Management of gout. Ann Intern Med 1979; 90: N 812-6.

22 Simkin P A. Campbell P M. Larson E B. Brief report: Gout in $\omega$ Heberden's nodes. Arthritis Rheum 1983: 26: 94-7.

23 Wallace S L. Robinson H. Masi A T. Decker J L. McCarty D J Yü T-F. Selected data on primary gout. Bull Rheum Dis $1978-9: \frac{\mathrm{C}}{\mathrm{C}}$ 29: $992-5$.

24 Franck W A. Bress N M. Singer F R. Krane S M. Rheumatic manifestations of Paget's disease of bone. Am J Med 1974; 56: $592-603$.

25 Macfarlane D G. Cardiovascular discase and gout: a function of sex and age. In: Dieppe P A, Doherty M, Macfarlane D, eds. Symposium on crystal related arthropathies. Ann Rheum Dis 1983: 42 (suppl 1): 9()-1 